\title{
Export Market Orientation and Organizational Knowledge Enhance Export Market Performance
}

\author{
Ng Kim-Soon ${ }^{1}$, Muosa Rahil Mostafa ${ }^{1}$, Ali Abusalah Elmabrok Mohammed ${ }^{1}$ \& Abd Rahman Ahmad ${ }^{1}$ \\ ${ }^{1}$ Faculty of Technology Management and Business, Universiti Tun Hussein Onn Malaysia, 86400 Batu Pahat, \\ Johor, Malaysia \\ Correspondence: Ng Kim-Soon, Faculty of Technology Management and Business, University Tun Hussein \\ Onn Malaysia, 86400 Batu Pahat, Johor, Malaysia. Tel: 607-453-3960. E-mail: ksng @uthm.edu.my
}

Received: October 11, 2015

Accepted: November 6, 2015

Online Published: November 25, 2015

doi: 10.5539/ibr.v8n12p80

URL: http://dx.doi.org/10.5539/ibr.v8n12p80

\begin{abstract}
Exporters exporting to the Arab Countries should focus on market orientation and organizational knowledge activities to enhance their export performance. Marketing concept suggests that the long term purpose of an organization is to satisfy customer needs for the purpose of maximizing profits. Thus, this study investigated the relationship between export market orientation, organizational knowledge and export market performance. The hypothesized relationships between export market orientation, organizational knowledge and export market performance were empirically tested through structure equation modeling. A total of 223 duly completed self-administrated survey questionnaires collected from each representative manufacturers who export to the Arab market were analyzed. The result shows that export market orientation and organizational knowledge positively influence export market performance. The square multiple correlations between the exogenous constructs and endogenous construct was found to be $49 \%$. It means that when there is one unit of increase in export market orientation and organizational knowledge, there will be 49 units of increase of export market performance for Malaysian manufacturers exporting to Arab countries. Result implies that exporters exporting to Arab countries should focus on market orientation and organizational knowledge activities in their organization to enhance export performance.
\end{abstract}

Keywords: export market orientation, organizational knowledge, market performance, knowledge management

\section{Introduction}

Market orientation is the firm's implementation of the marketing concept. It is also been considered as organizational cultures that are efficiently and effectively created for necessary behavior for the creation of superior value for customers and superior performance for the business. Market orientation is the combination of the generation of market intelligence, the dissemination of the intelligence and the organizational wide responsiveness. For an organization to have a strong market orientation, there is a need to direct its resources in a particular direction with the aim of monitoring continuously as per the changing market environment and customer expectations and demand (Singh, 2004). Market orientation needs to focus on two main contexts, that is customer orientation and competitor orientation to make the organization innovative (Sørensen, 2009). Sorensen also added that competitor orientation is positively related with the market share of the organization (Mousa et al., 2013). Many organizations inadvertently discourage innovation through their organizational practices (e.g. planning, budgeting, and rewards). In addition, many organizations have cultures that drive short-term results and risk avoidance. Without changing some organizational practices and building a culture of innovation, leaders will not close the innovation gap (Weiss \& Legrand, 2011). According to Fang et al. (2014), in order to sustain competitive advantage in an advanced market environment, organizations must retain and accumulate resources with frequent function of assets and market knowledge. Over the course of time, the marketing concept has evolved to reflect the philosophy of doing business that can be considered as the fundamental of successful organization's culture (Baker et al., 1994; Houston, 1986; Hunt \& Morgan, 1995; Lusch \& Laczniak, 1987; Slater \& Narver, 1995). Interest on market orientation research work has increased rapidly. Empirical evidence have shown that there is much emphasis on the importance of market orientation for better economic and commercial results (Mahmoud, 2010). This study adapt has adapted the market orientation theory and resource based theory to formulate the research framework of export market orientation and 
organizational knowledge as exogenous constructs with export market performance as endogenous. The aim of the study is to empirically examine the relationship of export market orientation, organizational knowledge and export market performance of Malaysian manufacturing companies exporting to Arab countries and enhance the literature in this area.

\section{Review of Literature}

Economic relations between Malaysia and Arab countries has been increasing in recent years. Arab countries have appeared to be the new trade destination for Malaysia's trade and investment. Thus, new approaches have been utilized for the international trade strategies by transferring from dependency on traditional export markets like US, Japan to Arab countries orientation (Hussin et al., 2011). The relationship between exports market orientation and organizational knowledge has been tested by many researchers. Market information collection and treatment is a major function of an innovational organization. Malaysia has been pursuing close relationship with the Arab region through proposed Free Trade Agreement (FTA) which can serve as a milestone for Malaysia to enlarge its Arab market. The Malaysian-Arab relationships on trade and business have long been established for mutual benefits. Malaysia is one of the rising stars in its fast economic and social developments with the main trading partners including the Arab region, ASEAN and the developed world after the country gained its independence (amcc website).

Malaysia's trade reported a MYR9.69 billion trade surplus in September of 2015, up from MYR9.33 billion a year earlier but below market consensus, as exports and imports grew faster than expected. Year-on-year, exports increased by 8.8 percent to MYR70.16 billion in September, the fastest growth since May 2014, following a 4.1 percent rise in August. Higher trade were with countries like France with RM 1.52 billion, China with RM 1.04 billion, India with RM 693.5 million, United States of America with RM 580.4 million and Republic of Korea with RM 482.2 million (METS, 2013). Table 1 shows Malaysia's top ten export destination for the year of March 2012-2013.

Table 1. Malaysia's top export destinations

\begin{tabular}{lcc}
\hline \multicolumn{1}{c}{ Countries } & Export value (RM billion) & Share of total exports $(\%)$ \\
\hline Singapore & 24.77 & 14.60 \\
Japan & 20.46 & 12.10 \\
PRC & 20.38 & 12.00 \\
USA & 14.08 & 8.30 \\
Thailand & 10.38 & 6.10 \\
Indonesia & 8.21 & 4.80 \\
ROK & 6.76 & 4.00 \\
Hong Kong & 6.36 & 3.80 \\
Australia & 6.16 & 3.60 \\
India & 5.98 & 3.50 \\
\hline
\end{tabular}

Source: METS, 2013.

Notice that Malaysia's top traditional market partners are from the ASEAN, EU countries and the United States. The economic relation between Malaysia and Arab countries has been positive and is growing in strength in recent years. Middle East countries is a potential emerging market for the Malaysian companies. Arab countries play a significant role in enhancing Malaysia's economic activities and is a gateway for Middle East market (Hussin et al., 2011). In view of the fact that Malaysia is in the process of setting up the Islamic Financial Hub and World Halal Hub, the Arab countries are highly attracted to this approach and are seen as a partner for trade exchange in both production and services. Apart from the religious affinity, Malaysia and Arab countries have significant relations economically and politically. Malaysian economy has been highly dependent on external trade. Trade plays an important role in the country's economy and in overall development.

\subsection{Organizational Knowledge and Performance}

Rhodes et al. (2008) reported that effect of organizational knowledge transfer on organizational performance has not been clearly examined in past research works. IT system significantly influences on organizational knowledge and this resulted in improvement on organizational performance. Work by Hajipour et al. (2011) base on resource based theory examining on industrial structure, organizational characteristics, organizational knowledge with organizational performance found that skills and accumulated knowledge enables performance. 
Industrial structure influences on organizational characteristics which in turn increases organizational performance. Toften and Olsen (2003) iterated that export market knowledge increases the relationship between export market information and export market performance. They added that researches on market knowledge have been investigated in past years, however more research works are needed to understand how organizational knowledge is utilized to understand how information usage lead to improve organizational performance. In order to develop organizational knowledge, there is a need for information to be incorporated, integrated and efficiently articulated in an organization. Gupta et al. (2000) acknowledged that organizational culture is important in facilitating, sharing, and creation of knowledge. Culture leads to improvement in individual skills and experience cumulating into organizational knowledge. Sitlington and Marshall (2011) examined the impact of decision on organizational knowledge with firm performance and found that organization restructure their culture and climate to maximize knowledge. Most previous studies have highlighted the importance of knowledge on organizational performance. In this paper, it has focused particularly on the impact of organizational knowledge on market performance of Malaysian manufacturing companies exporting to the Arab countries.

\subsection{Export Market Orientation and Export Market Performance}

In analyzing the relationship between market orientation and organizational performance, innovation has been identified as a crucial factor. Connor (1999), Han et al. (1998), Jaworski et al. (2000) have elaborated the theories and frameworks about the relationship between market orientation and innovation. Their focus are particularly on the large firms and investigating the relationship between market orientation and innovation. The nature of innovation in small firms is different from that of in large firms (Audretsch, 2001). Previous research works have found that market orientation has a positive influence on the performance of firm (Deshpandé \& Institute, 1999; Jaworski \& Kohli, 1993; Narver \& Slater, 1990). However, no support whatsoever for this relationship has also been reported (Slater \& Narver, 1994).

\section{Research Hypothesis}

This section is on research questions and formulating the hypothesis. It relates on past works on interaction of market orientation, organizational knowledge and export market performance to formulate the hypotheses for testing it in the context of Malaysian manufacturing companies. Specifically the research questions for effect of organizational knowledge and export market orientation on export market performance are:

1) Does organizational knowledge activities affect export market performance and;

2) Does export market orientation influences export market performance.

The resource-based approach has related that internal resources are essential in determining company performance and profitability (Barney, 1991). It focuses on how firm creates sustainable competitive advantage through their unique set of resources and knowledge it possessed. According to Peteraf and Barney (2003), this is associated with the creation of customer's superior value by utilizing specific and scarce resources in its actions. In this context, organizational knowledge and export market orientation are specific resources and activities a firm possess. Research works on organizational knowledge and market orientation addresses how organizations adapt to their own environment to develop competitive advantage (Mousa Rahil Mostafa, 2015). Organization knowledge is key to generating revenue. It enables the creation of new products and services (Tryon, 2012). Market orientation is considered as one of the main tool for organizational performance (Morgan et al., 2009; Murray et al., 2011). Thus, the hypotheses formulated to test these two elements and its influence on export market performance in a structure equation modeling are:

H1: Export market orientation positively influence export market performance for Malaysian manufacturing companies.

H2: Organizational knowledge positively influence export market performance in Malaysian manufacturing companies.

\section{Research Method}

This is a quantitative study. Self-administered questionnaire were used to collect the information required in this study. The questions were adapted from previous study. The measure for export market orientation was adopted from that used by Cadogan et al. (1999) and organization knowledge from Sanz-Valle et al. (2011). A 5 point Likert scale ranging from "strongly disagree" (1) to "strongly agree" (5) were used to scale these items measuring the independent variables. The dependent variable measures the export performance. The respondent from the respective companies was asked to rate their firm's export performance to the country among the emerging market of Arab countries where their firm has the most significant export business for the last 3 years. 
It thus measure the export venture performance to the most significant Arab market of the respective companies (Kim-Soon, 2004; Osman et al., 2009a; Osman et al., 2009b). The respondents are managers or owners who are knowledgeable of their respective companies export business. A total of 235 questionnaires were returned, of which 223 duly completed questionnaires were used in the final analyses.

\section{Data Analysis}

\subsection{Reliability Test}

The 223 data collected were analyzed using statistical Package for Social Science (SPSS) version 19 and Analysis of Moment Structure (AMOS 21) for Confirmatory Factor Analysis (CFA). For each of the item scale factor analysis was used to reduce the total number of items to a smaller number of underlying factors. The analyses showed that all measures exhibited high reliabilities with coefficient alphas ranging from 0.787 to 0.845 . Each items of the elements exceeded the acceptable level of 0.6 (Hair et al., 2010; Tabachnick \& Fidell, 2007) which means that all possessed the required factor loadings. Thus, all measurements are considered reliable and valid for hypothesis testing in the main study.

\subsection{Descriptive Statistics}

Table 2 shows the tests of normality and other descriptive statistics including mean, standard deviation, Skewness and Kurtosis. The values in the Table for skewness are between -0.27 and 0.39 , and the values of kurtosis are between 0.8 and 3.7 respectively. Based on the results of skewness and kurtosis, the result of the test indicated that the data of the study is within the acceptable level of normality assumptions.

Mean and standard deviation were included to indicate the validity of the data (see Table 3). Standard deviation as explained by Sutton et al. (2009) is considered as mean of the mean. Skewness and Kurtosis was used to determine whether the result is normally distributed or not. Skewness is considered as a measure of symmetry or more precisely. If the data indicate the same to the left and right of the center point, then it is considered as the data is symmetric. Kurtosis is a measure of whether the data are peaked or flat related to the normal distribution. The skewness for the normal distribution is zero, any data that is closer to zero is considered as a normally distributed. The kurtosis for a standard normal distribution is 3 . If the kurtosis value is nearer to zero, it means the data are normally distributed.

Table 2. Summary descriptive statistics, composite reliability and average variance extracted

\begin{tabular}{|c|c|c|c|c|c|}
\hline Constructs and items & $\mathrm{M}$ & $\mathrm{SD}$ & $\mathrm{CR}$ & $\alpha$ & AVE \\
\hline Market Orientation & & & 0.940 & & 0.796 \\
\hline Market Orientation & 3.92 & 0.677 & & 0.820 & \\
\hline Intelligence Generation & 3.97 & 0.695 & & 0.868 & \\
\hline Intelligence Dissemination & 4.00 & 0.638 & & 0.808 & \\
\hline Responsiveness & 4.00 & 0.644 & & 0.853 & \\
\hline Organizational knowledge & & & 0.854 & & 0.595 \\
\hline Knowledge Acquisition & 3.93 & 0.590 & & 0.840 & \\
\hline Knowledge Sharing & 3.96 & 0.664 & & 0.844 & \\
\hline Knowledge Interpretation & 4.15 & 0.590 & & 0.864 & \\
\hline Organizational Memory & 4.05 & 0.664 & & 0.816 & \\
\hline Knowledge Breadth & 4.10 & 0.644 & & 0.782 & \\
\hline Knowledge Depth & 4.14 & 0.624 & & 0.821 & \\
\hline Export Market Performance & 4.16 & 0.607 & 0.824 & 0.820 & 0.540 \\
\hline
\end{tabular}

Table 3. Descriptive statistics and test of normality

\begin{tabular}{llllllc}
\hline Variable & Min & Max & skew & c.r. & kurtosis & c.r. \\
\hline Coordinating Mechanisms & 2.5 & 5.0 & -0.98 & -5.977 & -0.111 & -0.339 \\
Responsiveness & 2.3 & 5.0 & -0.888 & -5.415 & -0.083 & -0.255 \\
Intelligence dissemination & 2.3 & 5.0 & -0.902 & -5.500 & -0.27 & -0.824 \\
Intelligence Generation & 2.3 & 5.0 & -0.909 & -5.543 & -0.015 & -0.046 \\
\hline
\end{tabular}




\begin{tabular}{|c|c|c|c|c|c|c|}
\hline Knowledge Acquisition & 2.5 & 4.8 & -0.978 & -5.962 & 0.076 & 0.233 \\
\hline Knowledge breadth & 2.3 & 5.0 & -1.161 & -7.080 & 0.618 & 1.884 \\
\hline Organizational Memory & 2.7 & 5.0 & -0.911 & -5.557 & 0.013 & 0.040 \\
\hline Knowledge Interpretation & 2.3 & 5.0 & -1.049 & -6.398 & 0.485 & 1.480 \\
\hline Knowledge Sharing & 2.6 & 5.0 & -0.918 & -5.595 & -0.276 & -0.841 \\
\hline Knowledge depth & 2.3 & 5.0 & -1.176 & -7.167 & 0.715 & 2.180 \\
\hline Export sales volume & 2.00 & 5.0 & -0.709 & -4.321 & 0.114 & 0.346 \\
\hline Export sales revenue & 2.00 & 5.0 & -0.438 & -2.669 & -0.583 & -1.778 \\
\hline Export profitability & 2.00 & 5.0 & -0.508 & -3.095 & -0.390 & -1.188 \\
\hline Market Share & 2.00 & 5.0 & -0.584 & -3.562 & -0.019 & -0.058 \\
\hline
\end{tabular}

\subsection{Goodness Fit Index and the Standardized Estimation of Analyses}

The measurement model of export market orientation, organizational knowledge and export market performance is tested using CFA. This is to determine the uni-dimensionality of each factor. The relationship between the four dimensions of export market orientation, six dimensions of organizational knowledge and export market performance as endogenous construct were examined through the proposed hypothesis via structural equation modeling technique.

Table 4 shows the results of CFA of the measures, Goodness Fit index and the standardized estimation of analyses. The finding implies that intelligence dissemination strongly influences export market performance. The AMOS output displays in Figure 1 and Table 4 show that the $\mathrm{R}^{2}$ between export market orientation, organizational knowledge and export market performance is 0.49 . This indicates that $49 \%$ of export market performance is explained by export market orientation and organizational knowledge. The beta coefficient for export market orientation and organizational knowledge was observed to be $(\beta=0.43)$ and $(\beta=0.45)$ with significant and positive relationship between export market orientation, organizational knowledge and export market performance at $\mathrm{p}<0.01$ level. Table 4 shows that the standard errors and the estimation by the standard error (critical ratio) indicated normally distribution of the variables (C.R. value of 1.96 or higher and -1.96 or lower indicates two sided significance at 95\% confident level (Byrne, 2013). Thus, the results support hypotheses $\mathrm{H} 1$ and $\mathrm{H} 2$, as the beta from export market orientation and organizational knowledge with export market performance are significant.

Table 4. CFA between export market orientation, organizational knowledge and export market performance

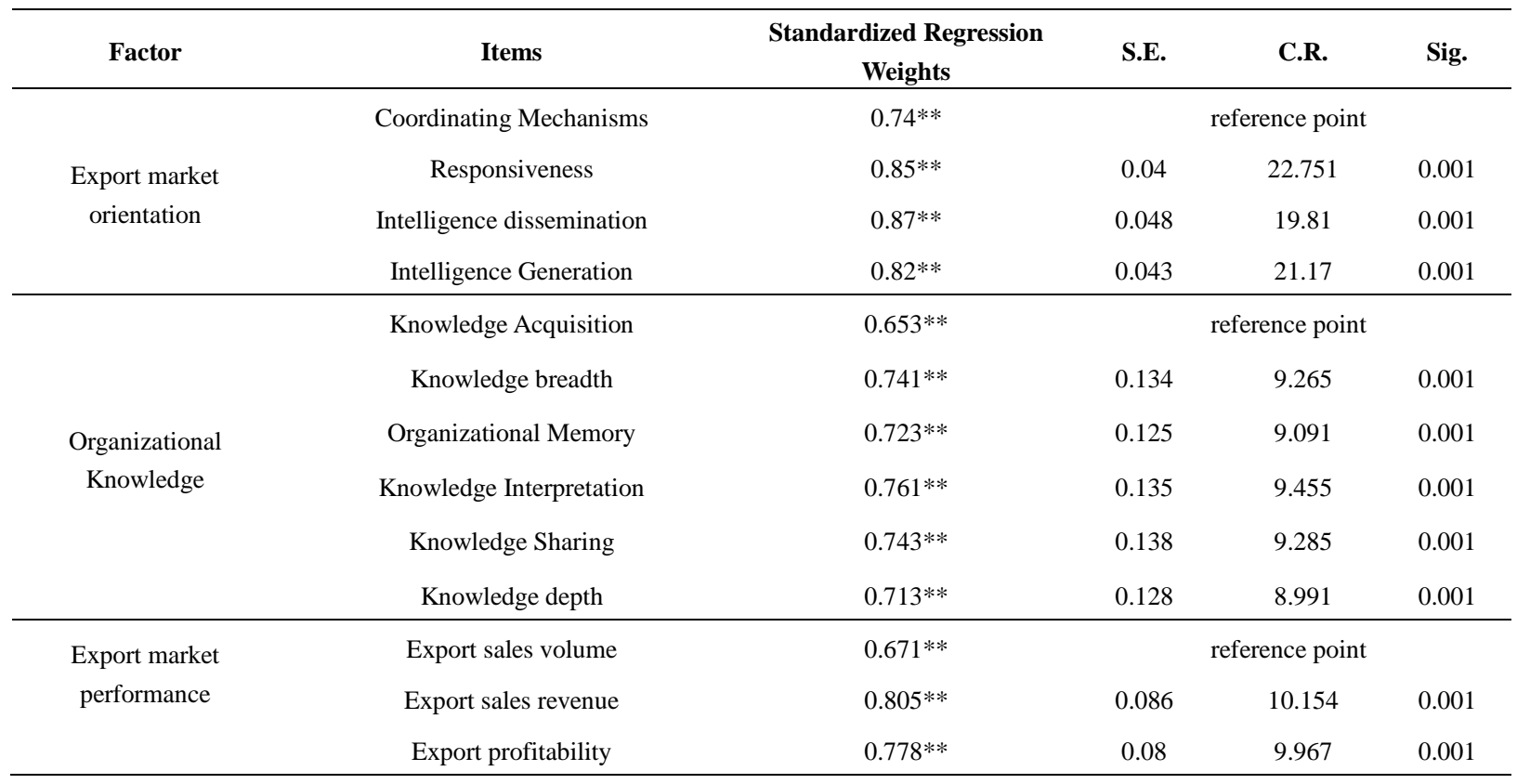




\begin{tabular}{|c|c|c|c|c|c|}
\hline & Market Share & $0.680 * *$ & 0.086 & 9.079 & 0.001 \\
\hline \multirow{11}{*}{$\begin{array}{l}\text { Goodness Fit index } \\
\text { and standardized } \\
\text { estimation }\end{array}$} & $\mathrm{R}^{2}$ & & $0.49 * *$ & & \\
\hline & Beta Coefficient (OK) & $0.45^{* *}$ & & & \\
\hline & Beta Coefficient (EMO) & & $0.43^{* *}$ & & \\
\hline & \multicolumn{4}{|c|}{ Goodness fit index } & \\
\hline & \multicolumn{2}{|l|}{ CMIN } & \multicolumn{3}{|c|}{138.019} \\
\hline & \multicolumn{2}{|l|}{ DF } & \multicolumn{3}{|c|}{74} \\
\hline & \multicolumn{2}{|l|}{ CMINDF } & \multicolumn{3}{|c|}{1.865} \\
\hline & \multicolumn{2}{|l|}{ GFI } & \multicolumn{3}{|c|}{0.927} \\
\hline & \multicolumn{2}{|l|}{ CFI } & \multicolumn{3}{|c|}{0.965} \\
\hline & \multicolumn{2}{|l|}{ TLI } & \multicolumn{3}{|c|}{0.957} \\
\hline & \multicolumn{2}{|l|}{ RMSEA } & \multicolumn{3}{|c|}{0.062} \\
\hline
\end{tabular}

Note. ${ }^{* *}$ Significant at $\mathrm{p}<0.001$; OK-Organizational Knowledge; EMO-Export Market Orientation.

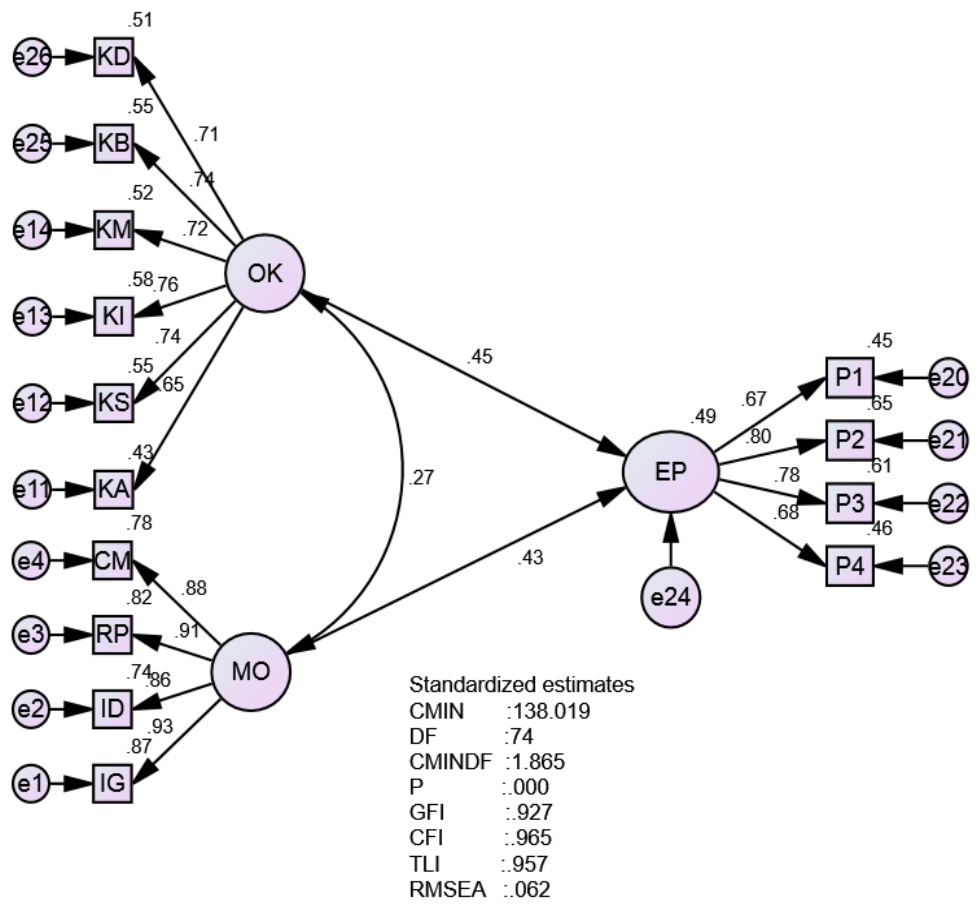

Figure 1. Structural relationship between dimensions of export market orientation, organizational knowledge and export market performance

\section{Research Implications}

The findings of this study should enhance managers understanding on how to identify and manage the strategies of market orientation and organizational knowledge to improve export market performance. This study has three managerial implications for managers and practitioners. First, the scale developed in this study may help managers diagnose the existence and level of orientation and export market performance strategies. Second, firm can enhance performance by focusing not only customer orientation but also emphasize on the important to be competitor oriented, be responsiveness and intelligence coordinate in order to have a high level of product value. Third, it brings awareness that different types of orientation strategies may result in the different effects on performance. 


\section{Conclusion}

The population frame for his study is the exporters from Federation of Malaysian Manufacturers exporting to the Arab countries. A total of 223 duly completed self-administrated survey questionnaires collected from each representative manufacturers who export to the Arab market were analyzed. It was found that export market orientation and organizational knowledge positively influence export market performance. Result implies that managers of companies exporting to Arab countries should focus on market orientation and managing knowledge in their organization to enhance export performance.

\section{Acknowledgments}

This research project is supported by Universiti Tun Hussein Onn Malaysia through its Multi-Discipline Research Grant Number 1322. The authors wish to thank the respondents who have spent their precious time and patience for participating in this project.

\section{References}

Audretsch, D. B. (2001). Research issues relating to structure, competition, and performance of small $\begin{array}{lllll}\text { technology-based firms. } & \text { Small Business }\end{array}$ http://dx.doi.org/10.1023/A:1011124607332

Baker, M. J., Black, C. D., \& Hart, S. J. (1994). Competitive success in sunrise and sunset industries (pp. 58-71). London: Prentice Hall.

Barney, J. B. (1991). Firm Resources and Sustained Competitive Advantage. Journal of Management, 17(1), 99-120.

Byrne, B. M. (2013). Structural equation modeling with AMOS: Basic concepts, applications, and programming. Routledge.

Cadogan, J. W., Adamantios, D., \& Charles, P. M. (1999). A Measure of Export Market Orientation: Scale Development and Cross-Cultural Validation. Journal of International Business Studies, 30(4), 689-707. Retrieved from http://www.jstor.org/stable/155340

Connor, T. (1999). Customer-led and market-oriented: A matter of balance. Strategic Management Journal, 20(12),

1157-1163. http://dx.doi.org/10.1002/(SICI)1097-0266(199912)20:12<1157::AID-SMJ72>3.0.CO;2-3

Deshpandé, R. (1999). Developing a market orientation. California : Sage Publications.

Fang et al. (2014). Internal market orientation, market capabilities and learning orientation. European Journal of Marketing, 48(1/2), 9-9. http://dx.doi.org/10.1108/EJM-06-2010-0353

Gupta, B. I., Lakshmi, S., \& Aronson, J. E. (2000). Knowledge management: Practices and challenges. Industrial Management \& Data Systems, 100(1), 17-21. http://dx.doi.org/10.1108/02635570010273018

Hair, J. F., Wolfinbarger, M. F., Ortinau, D. J., \& Bush, R. P. (2010). Essentials of marketing research. McGraw-Hill/Irwin.

Hajipour, B., Talari, M., \& Shahin, A. (2011). An investigation of the relationships between industry structure, strategy type, organizational characteristics and organizational performance: A case study of the food and chemical industries of Iran. African Journal of Business Management, 5(16), 7085-7098.

Han, J. K., Kim, N., \& Srivastava, R. K. (1998). Market orientation and organizational performance: Is innovation a missing link? Journal of Marketing, 30-45. http://dx.doi.org/10.2307/1252285

Houston, F. S. (1986). The marketing concept: What it is and what it is not. Journal of Marketing, 81-87. http://dx.doi.org/10.1002/nvsm.1535

Hunt, S. D., \& Morgan, R. M. (1995). The comparative advantage theory of competition. Journal of Marketing, $1-15$.

Hussin et al. (2011). Capturing Arab gulf market: An analysis of Malaysian exports competitiveness in the market. African Journal of Business Management, 5(21), 8521-8535.

Jaworski, \& Kohli. (1993). Market orientation: Antecedents and consequences. Journal of Marketing, 53-70.

Jaworski et al. (2000). Market-driven versus driving markets. Journal of the Academy of Marketing Science, 28(1), 45-54. http://dx.doi.org/10.1177/0092070300281005 
Lusch, R. F., \& Laczniak, G. R. (1987). The evolving marketing concept, competitive intensity and organizational performance. Journal of the Academy of Marketing Science, 15(3), 1-11. http://dx.doi.org/10.1108/02656711111101728

Kim-Soon, N. (2004). Value of Export Information, Enhancement of Export Marketing Competency, Environmental Characteristics and Export Venture Performance (Unpublished Doctoral Dissertation, Universiti Sains Malaysia, Penang).

Mahmoud, M. A. (2010). Market orientation and business performance among SMEs in Ghana. International Business Research, 4(1), 241. http://dx.doi.org/10.5539/ibr.v4n1p241

Mousa, R. M. (2015). Export Market Orientation, Organizational Knowledge and Export Market Performance: The Mediating Effect of Organizational Innovation ( $\mathrm{PhD}$ Thesis, Universiti Tun Hussein Onn Malaysia).

Mousa, R. M., Kim-Soon, N., \& Huam, H. T. (2013). Effect of Export Market Orientation on Organizational Innovation: A Structural Equation Model Analysis. Australian Journal of Basic and Applied Sciences, 7(6), 371-377.

Morgan, D., Vorhies, W., \& Mason, C. H. (2009). Market orientation, marketing capabilities, and firm performance. Strategic Management Journal, 30(8), 909-920. http://dx.doi.org/10.1002/smj.764

Murray et al. (2011). Market orientation and performance of export ventures: The process through marketing capabilities and competitive advantages. Journal of the Academy of Marketing Science, 39(2), 252-269. http://dx.doi.org/10.1007/s11747-010-0195-4

Narver, J. C., \& Slater, S. F. (1990). The effect of a market orientation on business profitability. Journal of Marketing, 20-35.

Osman, M., Ramayah, T., \& Kim-Soon, N. (2009a). Exporting to China and ASEAN countries: Perceived advancement in marketing competencies and export performance. Journal of Us-China Public Administration, 6(1), 15-22.

Osman, M., Ramayah, T., \& Kim-Soon, N. (2009b). Information and Marketing Competency of Malaysian Firms Exporting to Asian Markets. International Journal of Business and Management, 2(1), p. 33.

Peteraf, M. A., \& Barney, J. B. (2003). Unraveling the Resource-Based Tangle. Managerial \& Decision Economics, 24(4), 309-323. http://dx.doi.org/10.1002/mde.1126

Rhodes, J., Hung, R., Lok, P., Lien, B., \& Wu, C. M. (2008). Factors influencing organizational knowledge transfer: Implication for corporate performance. Journal of Knowledge Management, 12(3), 84-100. http://dx.doi.org/10.1108/13673270810875886

Sanz-Valle, R., Naranjo-Valencia, J. C., Jiménez-Jiménez, D., \& Perez-Caballero, L. (2011). Linking Organizational Learning with Technical Innovation and Organizational Culture. Journal of Knowledge Management, 15(6), 997-1015. http://dx.doi.org/10.1108/13673271111179334

Singh, S. (2004). Market orientation, corporate culture and business performance. Ashgate Publishing.

Sitlington, H., \& Marshall, V. (2011). Do downsizing decisions affect organisational knowledge and performance? Management Decision, 49(1), 116-129. http://dx.doi.org/10.1108/00251741111094473

Slater, S. F., \& Narver, J. C. (1994). Does competitive environment moderate the market orientation-performance relationship? Journal of Marketing, 58, 46-55. http://dx.doi.org/10.2307/1252250

Slater, S. F., \& Narver, J. C. (1995). Market orientation and the learning organization. Journal of Marketing, 63-74.

Sørensen, H. E. (2009). Why competitors matter for market orientation. European Journal of Marketing, 43(5/6), 735-761. http://dx.doi.org/10.1108/03090560910947025

Sutton, R. M., Niles, Dana, Nysaether, Jon, Abella, Benjamin, S., Arbogast, Kristy, B., Nishisaki, Akira, Helfaer, \& Mark, A. (2009). Quantitative analysis of CPR quality during in-hospital resuscitation of older children and adolescents. Pediatrics, 124(2), 494-499. http://dx.doi.org/10.1542/peds.2008-1930

Tabachnick, B. G., \& Fidell, L. S. (2007). Experimental designs using ANOVA.Thomson/Brooks/Cole.

Toften, K., \& Olsen, S. O. (2003). Export market information use, organizational knowledge, and firm performance: A conceptual framework. International Marketing Review, 20(1), 95-110. http://dx.doi.org/10.1108/02651330310462284 
Weiss, D. S., \& Legrand, C. (2011). Innovative Intelligence: The Art and Practice of Leading Sustainable Innovation in Your Organization. Wiley.

\section{Copyrights}

Copyright for this article is retained by the author(s), with first publication rights granted to the journal.

This is an open-access article distributed under the terms and conditions of the Creative Commons Attribution license (http://creativecommons.org/licenses/by/3.0/). 